\title{
A new species of Mountain Viscacha (Chinchillidae: Lagidium Meyen) from the Ecuadorean Andes
}

\author{
KARIM J. LEDESMA ${ }^{1,5}$, FLORIAN A. WERNER ${ }^{2}$, ANGEL E. SPOTORNO ${ }^{3} \&$ LUIS H. ALBUJA ${ }^{4}$ \\ ${ }^{1}$ Centro de Ornitología y Biodiversidad, Calle Santa Rita 105, oficina 2. Urbanización Huertos de San Antonio Surco, Lima 33, Perú. \\ E-mail: kledes@yahoo.com \\ ${ }^{2}$ Albrecht-von-Haller-Institut für Pflanzenwissenschaften, Universität Göttingen, Untere Karspüle 2, 37073 Göttingen, Germany. \\ E-mail:florianwerner@yahoo.com \\ ${ }^{3}$ Laboratorio de Citogenética Evolutiva, Instituto de Ciencias Biomédicas, Facultad de Medicina, Universidad de Chile, Casilla \\ 70061, Santiago 7, Chile.E-mail: aspotorn@med.uchile.cl \\ ${ }^{4}$ Instituto de Ciencias Biológicas, Escuela Politécnica Nacional, Apartado 17-01-2759, Quito, Ecuador. \\ E-mail: luis.albuja@epn.edu.pe \\ ${ }^{5}$ Corresponding author
}

\begin{abstract}
A new species of mountain viscacha, Lagidium ahuacaense, is described based on a specimen and a mitochondrial cytochrome $b(c y t b)$ sequence obtained from a second individual from Cerro El Ahuaca, Loja Province, Ecuador. In several external and craniodental measurements, the new species differed significantly from the three congeneric species (greatest length of skull, basilar, nasal length, palatilar length, length of diastema, least interorbital breadth, breadth of rostrum and skull height). The cyt $b$ sequence of the Ecuadorean viscacha differed by 14 exclusive nucleotide substitutions from all other sequences of Lagidium examined. Kimura 2-parameter (K2P) genetic distances of the Ecuadorean sequence were $8.1-11.0 \%$ to L. peruanum, 7.9-9.9\% to L. viscacia and 9.7\% to L. wolffsohni. The single known population of the newly described species may not comprise more than a few dozen individuals and warrants urgent conservation actions.
\end{abstract}

Key words: Andes; Ecuador; Hystricomorpha; phylogenetics; Rodentia; systematics; viscacha

\section{Resumen}

Una nueva especie de viscacha, Lagidium ahuacaense es descrita en base a un espécimen colectado en el Cerro El Ahuaca, Cariamanga, Ecuador, y al secuenciamiento del citocromo $b$ obtenido de un segundo individuo proveniente del mismo lugar. Varias de las medidas morfológicas externas y craneodentales de la nueva especie se diferenciaron significativamente de sus tres congéneres (máxima longitud del cráneo, longitud basilar, longitud nasal, longitud del paladar, longitud del diastema, mínima constricción interorbital, ancho del rostro y altura del cráneo). La secuencia del citocromo $b$ de la viscacha ecuatoriana difirió en 14 substituciones de nucleótidos exclusivos de las secuencias de sus otros congéneres. Las distancias genéticas Kimura 2-parámetros (K2P) de la viscacha ecuatoriana fueron de 8.1 a $11.0 \%$ con respecto a Lagidium peruanum, de 7.9 a $9.9 \%$ con respecto a L. viscacia, y de $9.7 \%$ con respeto a L. wolffsohni. La unica población de la nueva especie descrita podría estar conformada por solo unas pocas docenas de individuos por lo que requiere urgentemente de medidas de conservación.

\section{Introduction}

There are currently 381 species of mammals in Ecuador, of which rodents comprise 102 species (Albuja \& Arcos 2007). One of these rodent species is the mountain viscacha (Lagidium) first registered by Werner, Ledesma and Hidalgo (2006). 
The Chinchillidae form a family of hystricomorph rodents endemic to western and southern South America. This group comprises three genera. Monotypic Lagostomus Brookes (L. maximus Desmarest) inhabits the lowland plains of Central Argentina. Chinchilla Bennett has two species: one occurs in the Andean foothills and coastal mountains of Chile, C. laniger Bennett, and the other occurs in Andean Chile, Argentina and Bolivia, C. chinchilla (Lichtenstein) (Pacheco 2002; Redford \& Eisenberg 1992; Spotorno et al. 2004b; Woods \& Kilpatrick 2005). Lagidium Meyen ('mountain viscachas') comprises a debated number of species (Anderson 1997; Cabrera \& Yepes 1960; Ellerman 1940; Osgood 1943; Pearson 1948; Thomas 1907, 1921), related to deficient taxonomical definition of taxa and a limited morphological species differentiation within the genus. Currently, three species are most widely accepted, Lagidium wolffsohni (Thomas), L. viscacia (Molina) and L. peruanum Meyen (e.g., Eisenberg \& Redford 1999; Woods \& Kilpatrick 2005); some earlier authors additionally recognize L. v. boxi (Thomas) from Patagonia as a valid species (Cabrera \& Yepes 1960; Weir 1974; Pearson 1995). None of these species is known to occur north of central Peru. Lagidium wolffsohni is native to montane southern Argentina and adjacent Chile (Mares \& Ojeda 1982; Redford \& Eisenberg 1992). Lagidium viscacia is found in southernmost Peru along the Andes of Bolivia to South-central Chile and Argentina (Eisenberg \& Redford 1999; Rowlands 1974). Lagidium peruanum inhabits the central Andes (Puna), the western slope, and the lomas (i.e., moist vegetation of foggy coastal hills) of central and southern Peru (Eisenberg \& Redford 1999; Pacheco 2002; Pearson 1957) and reaches northernmost Chile (Eisenberg \& Redford 1999). This species is most commonly found at 3,000-5,000 $\mathrm{m}$ but descends to $600 \mathrm{~m}$ in the lomas (Pearson 1957; Grimwood 1969; Redford \& Eisenberg 1992). The documented northern range limit of L. peruanum is at $9-10^{\circ}$ southern latitude (Grimwood 1969; Pacheco 2002; Puig et al. 1998; Rowlands 1974), 500-600 km south of the recently discovered Ecuadorean Lagidium population at $4^{\circ}$ South (Werner et al. 2006). Prior to the discovery of Lagidium in Ecuador, the northern range limit of $L$. peruanum was also equivalent to the distribution of the entire Chinchillidae.

Mountain viscachas strongly depend on rocky surfaces as habitat (rock faces, boulder fields), where they den in deep crevices and caves, rarely foraging at distances greater than a few dozen meters from their shelters (Grimwood 1969; Pearson 1948; Walker et al. 2000a, 2000b). The resulting poor dispersal qualities of mountain viscachas and the considerable degree of geographical isolation of the Ecuadorean population raised questions about its origin and taxonomic status. Unlike in Chinchilla the fur of Lagidium is not of economic value (Pearson 1948). Nonetheless, its presence in Ecuador may be of anthropogenic origin.

In this study, we analyze external and craniodental measurements and DNA sequences from the mitochondrial cytochrome $b$ gene of Lagidium samples, including the Ecuadorean viscacha. These analyses allowed us to evaluate the taxonomic distinctiveness of the Ecuadorean viscacha, to discard doubts about its natural occurrence, to reject the null hypothesis that it belongs to any described species of Lagidium, and therefore, to formally describe it as a new species.

\section{Methods}

\section{Morphological analysis}

We examined one adult specimen of viscacha collected at Cerro El Ahuaca in Ecuador, which constitutes the holotype specimen of the new species. We did not collect additional animals for fearing of further endangering the presumably small population of viscachas at Cerro El Ahuaca. The holotype specimen is deposited at the Museum of the Escuela Nacional Politécnica of Quito, Ecuador (MEPN 10237). Anatomical comparisons were performed with 33 adult specimens of Lagidium peruanum, 35 of L. viscacia and three of L. wolfssohni collected from locations in Peru, Chile, and Argentina (see Appendix). The latter species is very poorly represented in museum collections. Adult specimens were identified through the information on museum tags and/or by taking into consideration size and maturity of the skull. 
External measurements of the Ecuadorean specimen were made with a caliper before dissection. External measurements of all other specimens of Lagidium were obtained from specimen tags and museum databases. Craniodental dimensions of all specimens were measured with a digital caliper to the nearest $0.01 \mathrm{~mm}$. Color classifications for the holotype were based on Smithe (1975). Measurements were taken following Anderson (1997), Anderson et al. (1987), and Voss et al. (2001) as follows: i) External: Head and Body Length (HBL), distance from tip of the last vertebra to nose tip; Tail Length (T), length of the tail vertebrae; Total Length (TL), including body and tail length; Hind Foot Length (HFL), length of the right foot without claws; Ear Length (EL), maximum length between the ear notch and the tip of the ear; Weight (W) in kilograms. ii) Craniodental: Greatest Length of skull (GLS), from anterior border of premaxillaries to posteriormost extension of skull; Condyle-Incisive Length (CIL), from the greater curvature of an upper incisor to the articular surface of the occipital condyle of the same side; Basilar (B), from posteriormost edge of incisor alveolae to anteriormost point of foramen magnum; Condylo Basilar Length (CBL), from the posterior edges of alveolae of first incisors to the posteriormost projection of the occipital condyles; Least of Interorbital Breadth (LIB), least distance across the frontal bones between the orbital fossae; Zygomatic Breadth (ZB), greatest transverse dimension across the squamosal zygomatic processes; Breadth of Rostrum (BR), measured just inside the anteroventral edge of the zygomatic plate; Nasal Length (NL), greatest anterior-posterior dimension of one nasal bone; Nasal Breadth (NB) greatest width of one basal bone; Zygomatic Length (ZL), from the posterior margin of the infraorbital foramen to the posterolateral corner of the zygomatic arch; Palatilar Length (PL) measured from the posterior edges of alveolae of first incisors to anteriormost point of posterior edge of palate; Least Palatal Breadth (LPB), breadth of palate between closest alveolar margins; Skull Height ( $\mathrm{SH}$ ), distance between the basiooccipito-palatal plane and the dorsalmost edge of the sagittal crest; Lambdoidal Breadth (LB), greatest breadth of skull across lambdoidal ridges; Length of Diastema (LD), from the crown of the first maxillary molar to the exposed lesser curvature of the upper incisor of the same side; Breadth of Incisive Foramina (BIF), greatest transverse dimension across both incisive foramina; Molar Row (MR), occlusal length of the maxillary molar row; Breadth of Molar 1 (BM1), breadth of first molar across the protocone-paracone cusp pair; Length of Orbital Fossa (LOF), greatest dimension of the orbital fossa inside the maxillary and squamosal roots of the zygomatic arch; Breadth of Nasal Aperture (BNA), greatest width across internal side nasals; Height of Coronoid Process (HCP), from the base of the ramus to the tip of the coronoid process; Height of Ramus (HR), height of the ramus between $\mathrm{m} 2$ and $\mathrm{m} 3$.

Morphological comparisons were performed with all nominal species of Lagidium, with emphasis on $L$. peruanum to facilitate field identification of the taxon. Geographically, L. peruanum is the closest nominal species to the Ecuadorean population, although their presently known ranges are separated by $500-600 \mathrm{~km}$ (Werner et al. 2006). Confusion with other species of Lagidium is precluded by allopatric distribution, with distances of over $1,000 \mathrm{~km}$ between ranges.

Since data were distributed normally for all variables (Kolmogorov-Smirnov test), we used Student's $t$ test to compare external and craniodental measurements of the single Ecuadorean specimen with specimens of each of the other Lagidium species (Sokal \& Rohlf 1995, p. 227 ff.). The significance level was set to $P<$ 0.05 .

Because gender did not significantly influence external or craniodental measurements in the two species (L. peruanum, $L$. viscacia) for which sufficient information for testing was available (t-test; $P>0.05$ ), we did not discriminate between sexes for morphometric analyses (see also Pearson 1948, p. 354, regarding low sexual dimorphism in L. peruanum). We performed principal component analysis (PCA) over a group of 13 measurements (GLS, LIB, ZB, BR, ZL, LPB, SH, LB, LD, MR, BM1, LOF, PL). Principal components were extracted from a correlation matrix and computed after transformation of variables to their natural logarithms to reduce scaling effects. 


\section{Molecular analysis}

Taxon sampling and outgroup selection

Because the tissue sample of the holotype was contaminated by preservatives, we used an ear tissue sample collected from a second, living viscacha at Cerro El Ahuaca that was caught by means of a net on 25 September 2006. Sampling followed the guidelines of the American Society of Mammalogists for animal care and use (Animal Care and Use Committee 1998). Seven new sequences of cytochrome $b$ (cyt $b$ ) together with 14 sequences obtained from GenBank were used. Dinomys branickii Peters (Dinomyidae), sister-group to Chinchillidae, was chosen as outgroup of the data set (Huchon and Douzery 2001). DNA was extracted from blood, liver or skin samples fixed in $75 \%$ alcohol using sodium dodecyl sulfate-proteinase $\mathrm{KCl}$ extraction and alcohol precipitation (Maniatis et al. 1992). Specimens studied are listed in Appendix, with GenBank accession numbers and voucher details.

DNA extraction, PCR amplification and sequencing

The mitochondrial cyt $b$ was amplified via the polymerase chain reaction (PCR) using Taq DNA polymerase (Promega, Madison, WI). PCR was applied using primers LGlu 14724a, H15050 and H15400, following Anderson et al. (1981); the thermal profile was of $95^{\circ} \mathrm{C}$ denaturation $(45 \mathrm{~s}), 54^{\circ} \mathrm{C}$ annealing (30 s), and a final $72^{\circ} \mathrm{C}$ extension $(1 \mathrm{~min})$ for 30 cycles. Double-stranded PCR products were purified by Wizard PCR Preps (Promega, Madison, WI). The thermal protocol for cycle sequencing using the Gibco-BRLs kit (Life Technologies, Rocklive, MA), was according to the manufacturer's recommendations. PCR products were analyzed in an ABI Prism 310 automated sequencer using the Big Dye Terminator Kit from Perkin Elmer (Applied Biosystems, Foster City, CA) according to the manufacturer's recommendations.

Phylogenetic analyses

Sequences were aligned using Clustal X (Higgins et al. 1992) and proofed by eye, resulting in an alignment with 503 positions. Kimura 2-parameter (K2P) distances were calculated with MacClade 3.0 (Maddison \& Maddison 1992). Maximum parsimony (MP), maximum likelihood (ML) and neighbor-joining (NJ) analyses were carried out with PAUP* version 4.0b10 (Swofford 2000). MP heuristic searches were conducted with the following options implemented: heuristic search mode, 10 random-addition-sequence replicates, tree bisection-reconnection (TBR) branch swapping, MULTrees option on, and collapse zerolength branches off. All characters were treated as equally weighted and unordered. Non-parametric bootstrapping values (BS) were generated as heuristic searches with 1,000 resamplings, each with ten random-addition replicates. Where more than one most parsimonious tree was found, trees were summarized in a strict consensus tree. In a first step, the analyses were compared to check for putative incongruence. Based on Mason-Gamer and Kellog (1996), incongruent accessions were identified by inspecting bootstrap values above $70 \%$.

Modeltest version 3.7 (Posada and Crandall 1998) was used to select a model of evolution for the ML analysis, performing a hierarchical likelihood ratio test (hLRT). For the ML analysis the substitution model HKY85 (Hasegawa et al. 1985) was chosen as providing the best fit $(\mathrm{A}=0.288, \mathrm{C}=0.277, \mathrm{G}=0.155$ and $\mathrm{T}=$ 0.280). The ML analysis was performed as heuristic search using ten random-sequence addition replicates, MULTrees option on, collapse zero length branches off, and TBR branch swapping. The confidence of branching was assessed with PAUP* 4.0b10 (Swofford 2000), using 500 non-parametric bootstrap resamplings generated as heuristic searches using a neighbor-joining tree as starting tree. The $\mathrm{NJ}$ analysis and assessment of BS was conducted using PAUP* 4.0b10 (Swofford 2000) with default settings and HKY85 implemented. 


\section{Results}

Morphology

External measurements place the Ecuadorean specimen as a medium-sized species of Lagidium, larger than L. peruanum, similar to the small northern subspecies of L. viscacia and slightly smaller than southern subspecies of L. viscacia or L. wolffsohni (Fig. 1). The tail length of the Ecuadorean specimen was larger than that reported for any species of Lagidium.

Relative skull height (GLS/SH) of the Ecuadorean specimen was smaller than in any congener. However, many size measurements of the Ecuadorean specimen exceeded those of L. peruanum considerably. For instance, greatest length of skull, basilar, nasal length, palatilar length and length of diastema were significantly larger. These characteristics make the skull of the Ecuadorean specimen appear flatter, more elongated than skulls of $L$. peruanum. Several measurements such as least interorbital breadth, breadth of rostrum and skull height were significantly different between the Ecuadorean specimen and L. viscacia and $L$. wolffsohni (Table 1).

Principal component summaries of multivariate relationships confirm the distinctiveness of the Ecuadorean taxon (Fig. 2). Principal component 1 (62.3\% of total variance explained) is a general size axis, with all cranial variables loading negative and mostly high (Table 2). Principal component 2 (variance: $10.1 \%$ ) is strongly influenced by rostrum breadth (BR), which is relatively wide in the Ecuadorean specimen and L. peruanum (Table 2).

\section{Phylogenetics}

Substantial genetic divergence within species was found for $L$. peruanum and L. viscacia. Populations of L. peruanum from Arica, near the southern limit of the species range in northernmost Chile, were distinct from L. peruanum from southern and central Peru. The K2P distances between the Arica specimens and the other L. peruanum haplotypes were 6.1-8.2\%. Moreover, there were pronounced molecular divergences among $L$. wolffsohni and 3 subspecies of $L$. viscacia from the southern Andes. The two northernmost samples (L.v. perlutea) were 5.0-5.4\% divergent from the nearest southern subspecies, L. v. viscacia, but 7.7-8.6\% divergent from L. v. boxi. Lagidium v. boxi differed by 5.5-5.9\% from $L$. wolffsohni.

The Ecuadorean sequence was clearly divergent by 14 exclusive nucleotide substitutions, among which three were non-synonymous ones at sites 350, 361 and 368. The Kimura 2-parameter (K2P) genetic distances between the Ecuadorean viscacha sequence and the other 15 Lagidium sequences was $8.1-11.0 \%$ to $L$. peruanum individuals (10.0-11.0\% to the Arica specimens, $8.1-10.0 \%$ to the remainder specimens of $L$. peruanum), 7.9-9.9\% to individuals of $L$. viscacia (9.3-9.9\% to $L$. v. boxi, 7.9-9.0\% to other subspecies of $L$. viscacia) and $9.7 \%$ to $L$. wolffsohni. These distances were distinctly larger than the distance of 5.6-6.2\% that separates the two well-recognized Chinchilla species in the same tree, and well beyond the known range of intraspecific distances known for rodents (Bradley \& Baker 2001; Spotorno et al. 2004a; Baker \& Bradley 2006).

The MP analysis yielded four equally parsimonious trees of 342 steps (consistency index $(\mathrm{CI})=0.658$, retention index $(\mathrm{RI})=0.758$, and rescaled consistency index $(\mathrm{RC})=0.499)$. Of a total of 503 character sites, 321 were constant, 60 autapomorphic and 122 parsimony-informative.

In our topology, the genera Chinchilla and Lagidium form monophyletic lineages in a robust sister-group relationship. Within Lagidium, L. peruanum forms a monophyletic clade albeit with low BS support (Fig. 3). Specimens from the southern extreme of the species range in Arica are placed sister to the northern populations. $L$. viscacia is not resolved as a monophyletic taxon, because $L$. $v$. boxi is placed in a clade with $L$. wolffsohni and $L$. v. perlutea, whereas $L$. v. viscacia is sister to a $L$. peruanum clade without support. The new Lagidum species represents a sister lineage to all other Lagidium species sampled, albeit without BS support. The morphological differences, genetic distances, and the substantial degree of geographical isolation strongly support the recognition of the Ecuadorean Lagidium as a new species, which is named and described below. 


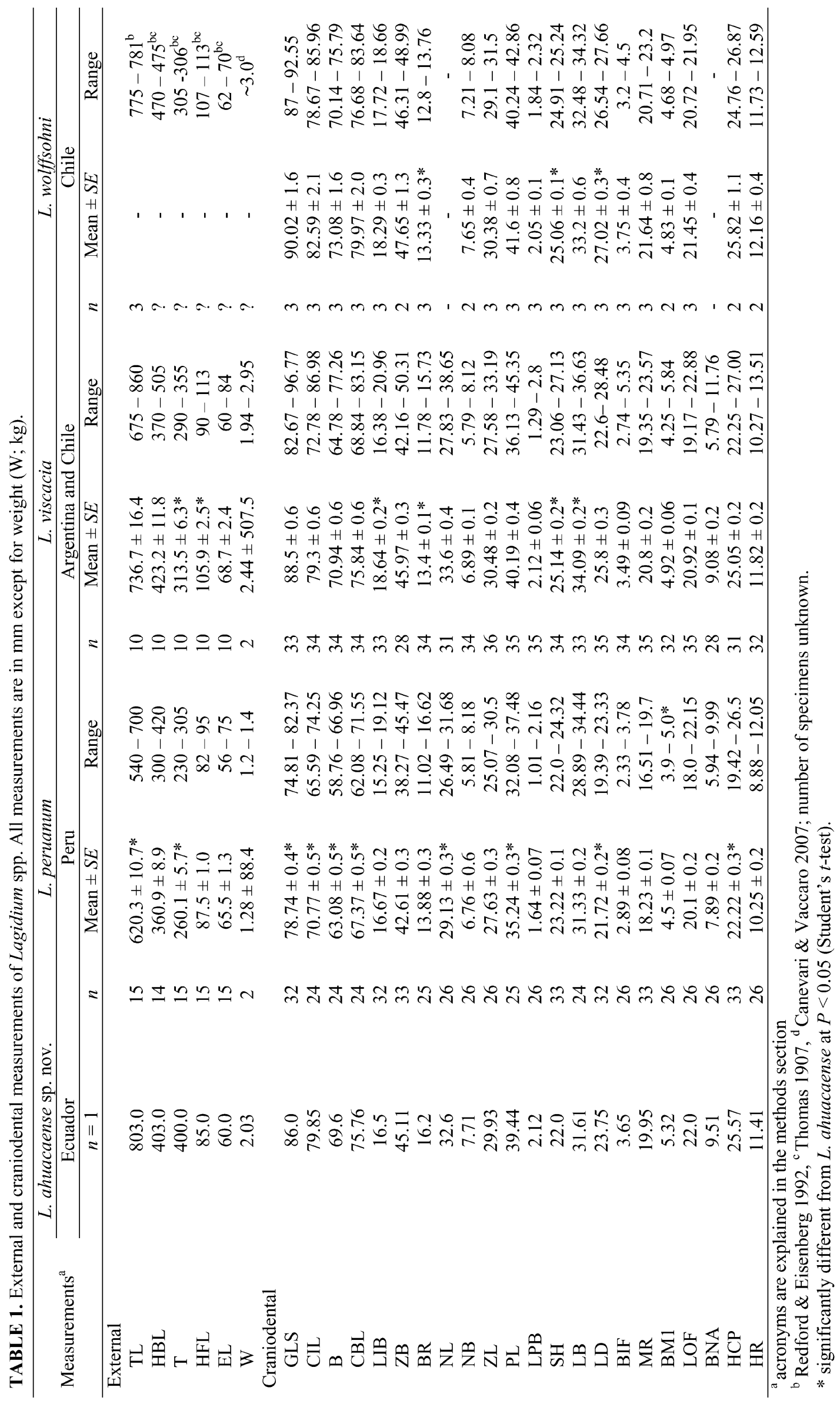


Lagidium ahuacaense, sp. nov.

Holotype. Adult male, skin and skull with mandibles, MEPN10237, collected by Danny Hidalgo on 22 March 2006. The skin is well preserved, except for one small hairless patch on the neck.

TABLE 2. Character loadings (scaled to their standard deviation), eigenvalues, and percentage variance explained on the first 4 components of a principal component analysis of log-transformed measurements of Lagidium spp. Variables are defined in the methods section.

\begin{tabular}{lllll}
\hline Variable & \multicolumn{3}{c}{ Principal component } \\
& 1 & 2 & 3 & 4 \\
\hline GLS & -0.982 & 0.024 & 0.034 & 0.066 \\
LIB & -0.714 & -0.302 & -0.429 & -0.265 \\
ZB & -0.906 & 0.137 & 0.043 & -0.028 \\
BR & -0.112 & 0.857 & -0.426 & 0.057 \\
ZL & -0.874 & -0.174 & 0.199 & 0.094 \\
LPB & -0.597 & -0.186 & -0.341 & 0.647 \\
SH & -0.799 & -0.357 & -0.064 & -0.135 \\
BB & -0.823 & -0.024 & -0.200 & -0.171 \\
LD & -0.909 & -0.001 & -0.002 & 0.137 \\
MR & -0.871 & -0.034 & 0.090 & -0.212 \\
BM1 & -0.668 & 0.415 & -0.023 & -0.236 \\
LOF & -0.657 & 0.316 & 0.553 & 0.138 \\
PL & -0.950 & 0.091 & 0.110 & 0.053 \\
Eigenvalue & 8.11 & 1.32 & 0.89 & 0.69 \\
Variance [\%] & 62.35 & 10.15 & 6.88 & 5.34 \\
\hline
\end{tabular}

Type locality. Cerro El Ahuaca, Parroquia Cariamanga, Canton Calvas, Loja Province, Ecuador $\left(04^{\circ} 18^{\prime} 2^{\prime \prime} \mathrm{S}, 79^{\circ} 32^{\prime} 47^{\prime \prime} \mathrm{W}\right)$.

Distribution. Lagidium ahuacaense is known only from the type locality. Cerro El Ahuaca is a steep granite peak of inselberg nature situated $1 \mathrm{~km}$ from the town of Cariamanga. The species inhabits the entire altitudinal range of the peak $(1,950-2,480 \mathrm{~m})$ as evident from faecal pellets and feeding marks, but appears restricted to the immediate vicinity of extensive rocky surfaces (Werner et al. 2006). A more detailed habitat description is provided by Werner et al. (2006).

Etymology. The specific epithet refers to Cerro El Ahuaca. Common names: Ecuadorean mountain viscacha (English); viscacha de montaña ecuatoriana (Spanish).

Diagnosis. This is a medium-sized species of Lagidium, with a brown-grey fur coloration of the dorsal area and yellowish-grey coloration ventrally. Ears are blackish with cream-colored fringes. Hands and feet bear black hairs, palms and soles are naked and of blackish color. Dorsally, the tail has long coarse hairs, maroon with some cream in coloration, while the bottom of the tail has short, blackish brown hairs. The tip of the tail is covered with long hairs. Vibrissae are mostly black.

Comparisons. In L. peruanum, fur coloration can vary from creamy buff to dark grey (Meyen 1833; Pearson 1948). The holotype of L. ahuacaense is darker in color (dorsally and ventrally) than the dark grey individuals of $L$. peruanum examined for this study $(\mathrm{n}=20)$, which were suffused with more light hairs. Moreover, no L. peruanum showed such dark (almost black) coloration on the dorsum of the feet as the new species. As in L. peruanum, fur color in L. viscacia is highly variable. Dark grey individuals from Patagonia present a more conspicuous dark dorsal line than L. ahuacaense. Populations of $L$. wolffsohni are known by their ochre coloration (Canevari \& Vaccaro 2007). 


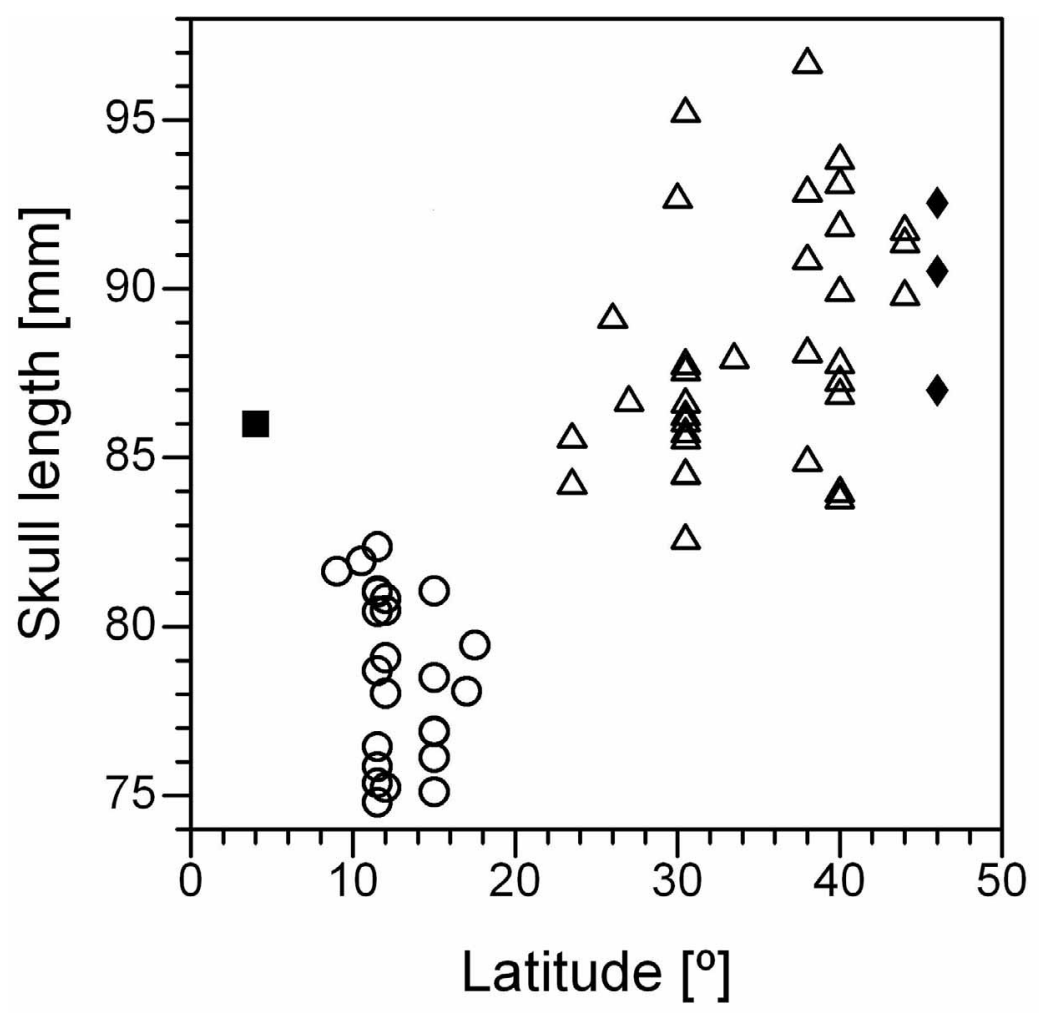

FIGURE 1. Skull length (GLS) and geographical distribution (latitude) of Lagidium specimens studied. L. peruanum (open circles), L. viscacia (open triangles), L. wolffsohni (filled diamonds), and L. ahuacaense sp. nov. (filled square).

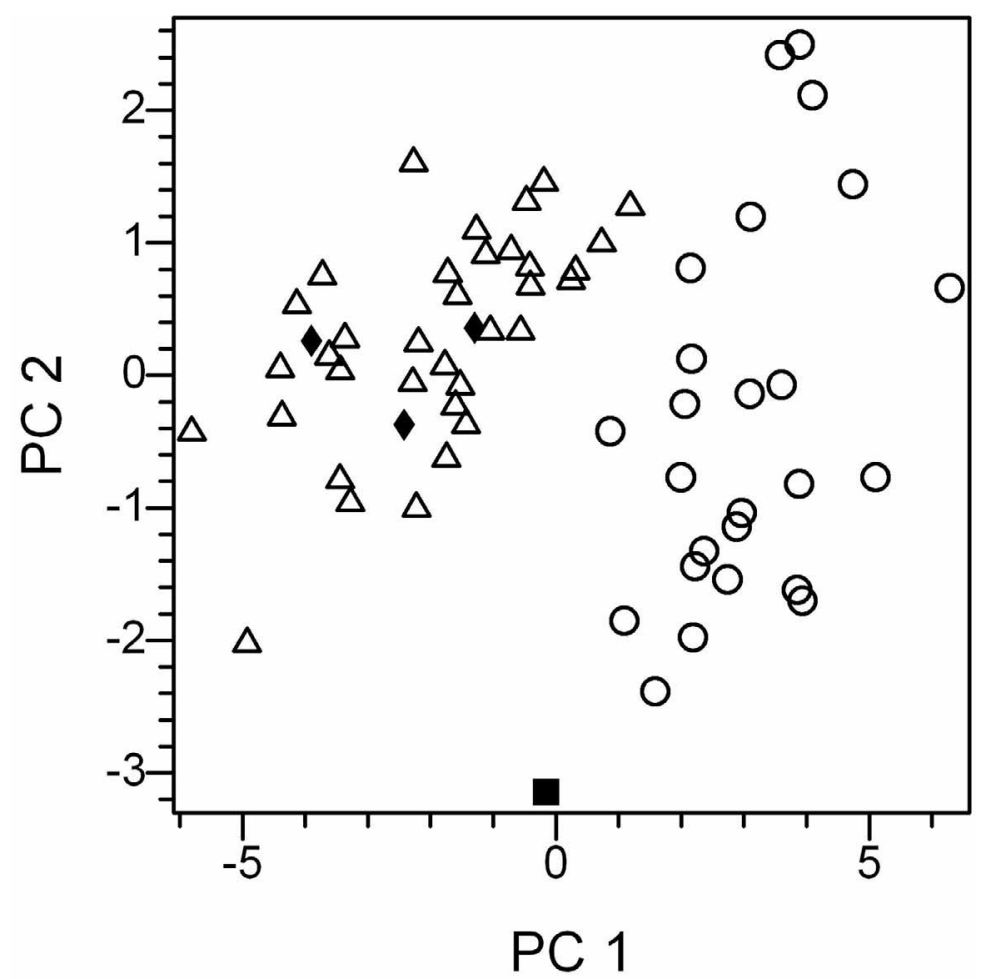

FIGURE 2. Multivariate relationships among Lagidium spp. Projections of individual specimen scores from principal component analysis on the 1 st and 2 nd factors of 13 log-transformed cranial measurements. Taxa indicated are: $L$. peruanum (open circles), L. viscacia (open triangles), L. wolffsohni (filled diamonds), and L. ahuacaense sp. nov. (filled squares). 
In dorsal view, $L$. ahuacaense has much more pronounced bending premaxillo-frontal sutures than $L$. peruanum; a wider rostrum and a narrower interorbital constriction than L. viscacia and L. wolffsohni. In lateral view, the braincase of $L$. ahuacaense is much less arched (vaulted) than that of L. peruanum, and slightly less arched than that of $L$. viscacia and $L$. wolffsohni; in addition, L. peruanum shows a slender jugal and $L$. wolffsohni exhibits somewhat longer paraoccipital processes, more separated from the bullae.

In ventral view, the posterior margin of the hard palate of $L$. peruanum is either smoothly squared or concave, with few individuals showing a rather poorly developed postpalatal process. The mesopterygoid fossa in L. peruanum and L. viscacia has less diverging sides than in L. ahuacaense. This fossa has parallel sides in $L$. wolffsohni, resembling a letter ' $U$ '. The basioccipital is relatively wider in $L$. peruanum than in $L$. ahuacaense. In L. viscacia and L. wolffsohni the basioccipital is less constricted by the bulla at its middle region and noticeably wider than in L. ahuacaense.

Measurements. External and craniodental measurements are listed in Table 1 and discussed below.

Description. Total length is $803 \mathrm{~mm}$. Body pelage wooly and grayish brown (Smoke Gray 45). Tail long with coarse hairs. Anterior dorsal pelage shorter than posterior pelage. Dorsal fur grayish with buffy and black tints. Medial dorsal area has a black longitudinal stripe. Length of dorsal hairs variable, with mean length ranging from $24 \mathrm{~mm}$ in the anterior region to $45 \mathrm{~mm}$ in the posterior region of the body. Dorsal cover hairs with a grey basal band (Medium Neutral Gray 84), a dark grey medium band (Dark Neutral Gray 83), and a cream-colored distal band (Cream 54). Guard hairs longer than cover hairs with two bands, a thin grey basal band (Medium Neutral Gray 84) and a thick black apical band (Jet Black 89). Length of guard hairs variable, averaging from $24 \mathrm{~mm}$ on the anterior region to $45 \mathrm{~mm}$ on the posterior region. Pelage of head resembling dorsal hair but shorter. Mystacial vibrissae thick and long $(18-147 \mathrm{~mm})$ and primarily dark brown with few scattered white hairs. Superciliary vibrissae scarce, up to $71 \mathrm{~mm}$ in length, thick and dark brown. In the holotype, one thick, dark brown genal vibrissa present (54 $\mathrm{mm}$ in length). Ear length is $60 \mathrm{~mm}$. Skin inside and outside of ears black, with abundant hairs on the upper basal area. Remainder outside of the ears covered with fine brown hairs bordered by white hairs, inside of ear sparsely covered with fine white hairs. Hairs in mentonian region, flanks of the body, sides of the throat and ventral region creamy white with a grey basal band (Medium Neutral Gray 84) and cream-colored white distal band (Cream 54). Fur of inguinal region ochre, with bands similar to those of ventral region. Length of ventral hairs 15-24 $\mathrm{mm}$ in the anterior region, $17-31 \mathrm{~mm}$ in the central region, and $21-31 \mathrm{~mm}$ in the posterior region. Fore feet substantially shorter than hind feet (36 versus $85 \mathrm{~mm}$ ). The four digits of fore- and hind feet each with a small and slightly curved claw of 4.0-6.5 mm. Tips of fingers large, spherical and fleshy. Hand and foot have three black pads with small cream-colored spots. First interdigital pad of hand spherical, smaller than the two other pads; medial pad on foot larger than the others; thenar and hypothenar long (Fig. 4).

Fur on fore feet primarily brown intermixed with few cream-colored hairs (Fig. 5). Fur on hind feet composed of cream-colored hairs intermixed with brown hairs from base to middle of foot, and dark brown hairs from middle to tip of the foot. Tail $400 \mathrm{~mm}$ in length, with long (21-143 mm) coarse hairs dorsally and short (12.5-29 mm) coarse hairs ventrally. Hairs of tail tip longer than those on the rest of tail, reaching up to $150 \mathrm{~mm}$ in length. Hair coloration on the upper tail divided into three categories: (1) basal region similar in color to dorsal region; (2) hairs of middle region including distal tail vertebrae light brown and medium brown hairs intermixed with cream-colored hairs; (3) tip of tail dark reddish brown (Raw Umber 223). Ventral tail hairs uniformly blackish brown (Sepia 119).

Skull elongated and compact with long axis slightly curved and depression in the supraorbital region (Fig. 6). Zygomatic arch relatively broad. Nasal bones slightly concave at the proximal region, curved and inflated toward the distal region. Lacrimal capsule well developed. Frontal bones constricted in the middle region (16.5 mm long). Frontal sinuses slightly inflated. Neither occipital external crest nor nuchal crest well developed. In contrast, occipital external protuberance well defined and most prominent posterior point of skull. In lateral view, posterior region of skull curved, nasal bones appear swollen. Premaxilla protrudes slightly beyond front of incisors. Zygomatic process broad in the posterior region. Tympanic bulla small (15.6 $\mathrm{mm}$ in length) and rounded at base with external auditory meatus point directed towards the superior region. 
Post-glenoid foramen large and cone-shaped with tip directed towards back of skull. From the ventral view, foramen magnum prominent, with maximum diameter of $11.2 \mathrm{~mm}$. Incisive foramina long and narrow, with a central crease that forms two indentations. Palate narrow in the anterior region and broader in the posterior region. Length of palate raised and extends to near M3. Pterigoid crest extends to posterior region of M2. Posterior margin of palate indented in the shape of a ' $\mathrm{W}^{\text {'. }}$. Mesopterygoid fossa deep. Oval foramen large (4.9 $\mathrm{mm}$ diameter); located at the posterior region and positioned lateral to pterygoid fossa.

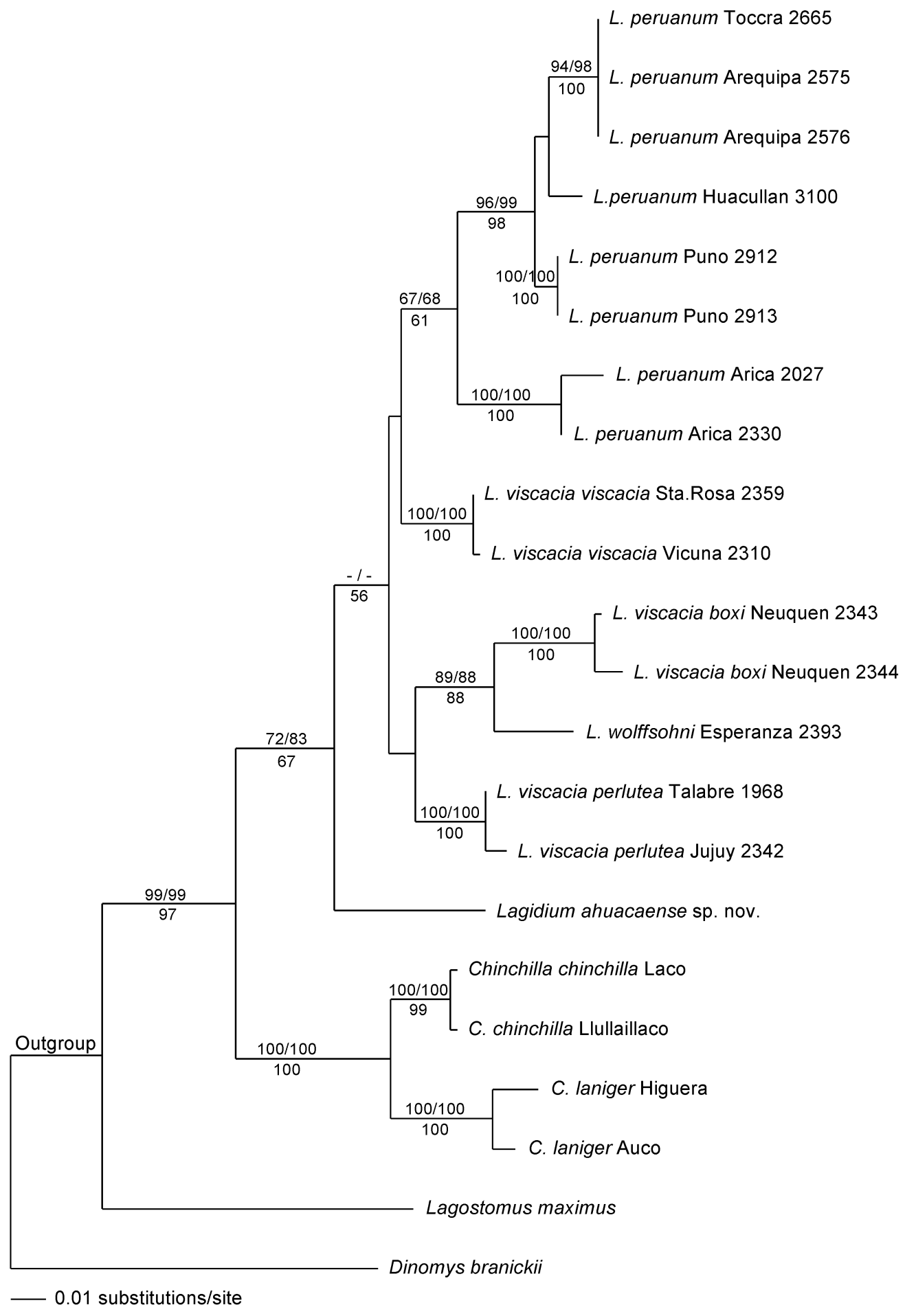

FIGURE 3. The most likely phylogram resulting from maximum likelihood analysis of the molecular data set. Bootstrap support values $\geq 50 \%$ are indicated at branches. Numbers on nodes represent bootstrap support values for maximumlikelihood/maximum-parsimony (above), and neighbor-joining distance analyses (below). 


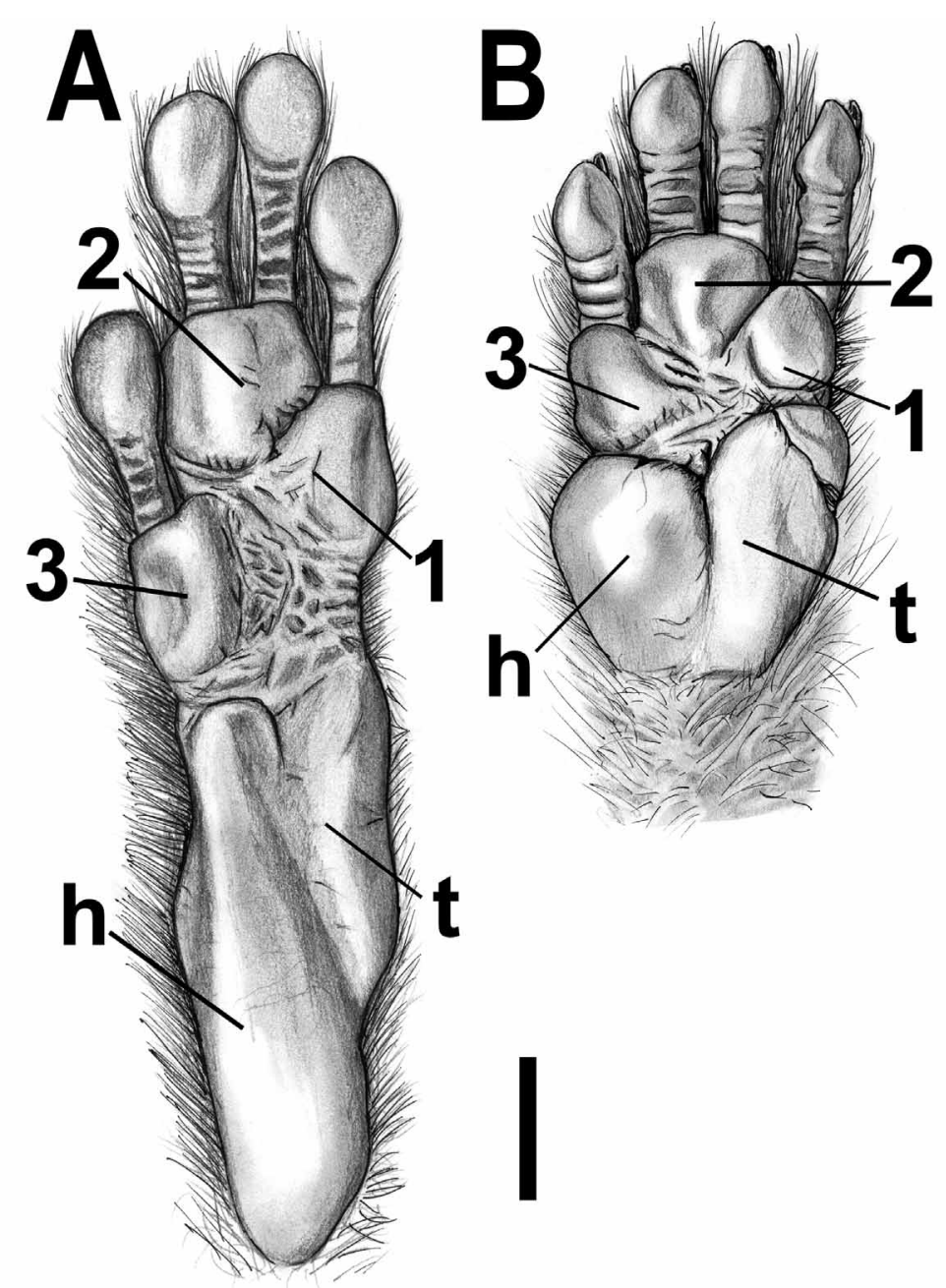

FIGURE 4. Plantar view of right hind foot $(\mathrm{A})$ and right fore foot $(\mathrm{B})$ of $L$. ahuacaense $\mathrm{sp} . \mathrm{nov} \cdot \mathrm{h}=$ hypothenar pad, $\mathrm{t}=$ thenar pad; $1-3=$ first through third interdigital pad. Scale bar $=10 \mathrm{~mm}$.

Structure of mandible robust with a blunt coronoid process directed towards the posterior and exterior regions. Rear mandible of symphysis located at same level as procingulum of $\mathrm{p} 4$. Condyle mandibles long. Foramen mandible located at internal base of coronoid process.

Dental rows converge in anterior region. Teeth of holotype characterized by low crowns. Dental formula: I 1/1, C 0/0, P 1/1, M 3/3, in total 20 teeth.

Incisors whitish, large and elongated. Anterior surfaces of teeth with grooves that extend over the entire length of teeth, but most apparent on upper incisors. Grooves of upper incisors yellowish. Tip of one of upper incisors of the holotype broken. Lower incisors distinctively beveled. Upper dental row, $19.95 \mathrm{~mm}$ in length. Molars with low crowns and of continuous growth. Each molar characterized by a flat crown with two transverse lamellae of enamel oriented diagonally to the extreme posterior lingual. P4 slightly larger than remainder teeth. Posterior lamella of M1 and M2 angled and curved towards posterior region, posterior lamellae of M3 form a straight right angle. Lower dental row, $18.1 \mathrm{~mm}$ in length, and converges in the anterior region, similar to upper row. Each molar with two transverse lamellae of enamel. Cingulum of p4 on the labial side with two prominent depressions, posterior depression more pronounced. In labial region of m1-m3, posterior lamellae more pronounced than those of the anterior region. Lingual region of $\mathrm{m} 1-\mathrm{m} 3$ with concave cingulum in the anterior lamella region; posterior region convex (Fig. 6). 


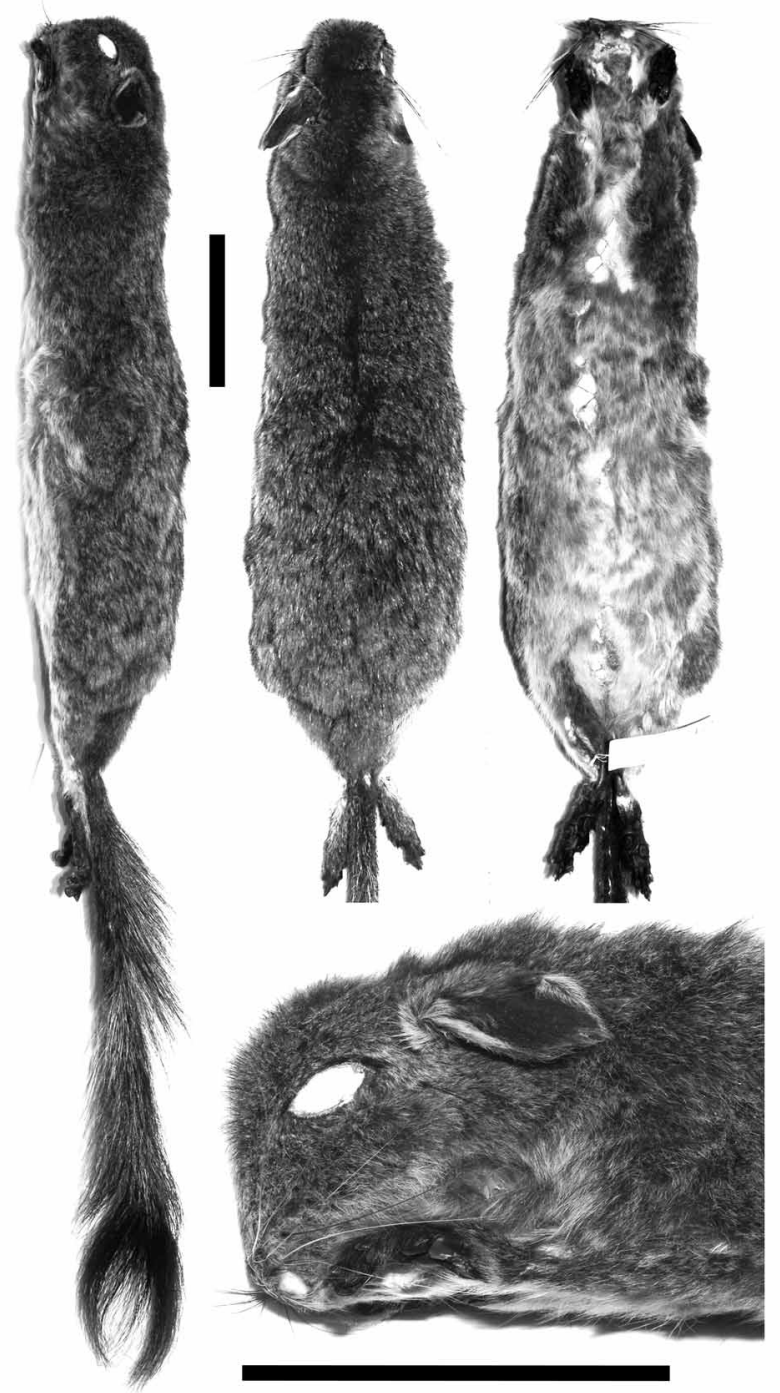

FIGURE 5. Skin of the holotype of Lagidium ahuacaense sp. nov. (MEPN 10237). Scale bar $=100 \mathrm{~mm}$.

\section{Discussion}

The Ecuadorean taxon differs significantly from all nominal species in several external and craniodental measurements. Univariate differences are particularly pronounced with respect to L. peruanum, the only nominal species occurring within a range of ca. 1,000 km (Fig. 1; Table 1). Although our phylogenetic analysis could not clearly resolve the relationship of L. ahuacaense to the hitherto accepted Lagidium species, the genetic distance of $L$. ahuacaense from its congeners is substantially greater than the known range of intraspecific distances in rodents (e.g., Baker \& Bradley 2006). This invalidates the notion of an anthropogenic origin and strongly supports the recognition of the Ecuadorean taxon as a new species.

The present study revealed a substantial degree of genetic divergence within two nominal species of Lagidium (L. peruanum and L. viscacia). Moreover, both molecular and multivariate analysis of craniodental measurements failed to differentiate $L$. wolffsohni from L. viscacia, indicating that the genus is in need of a thorough taxonomic revision. Wilson \& Reeder (2005) listed 22 taxa for the genus Lagidium that had originally been described as species, mostly by Thomas (e.g., Thomas 1907, 1921). Although the genus has never been treated comprehensively, 18 of these taxa are currently treated as subspecies of $L$. peruanum and $L$. viscacia. Our results suggest that some of those taxa may merit recognition as species (see also Spotorno et al. 2004a). 

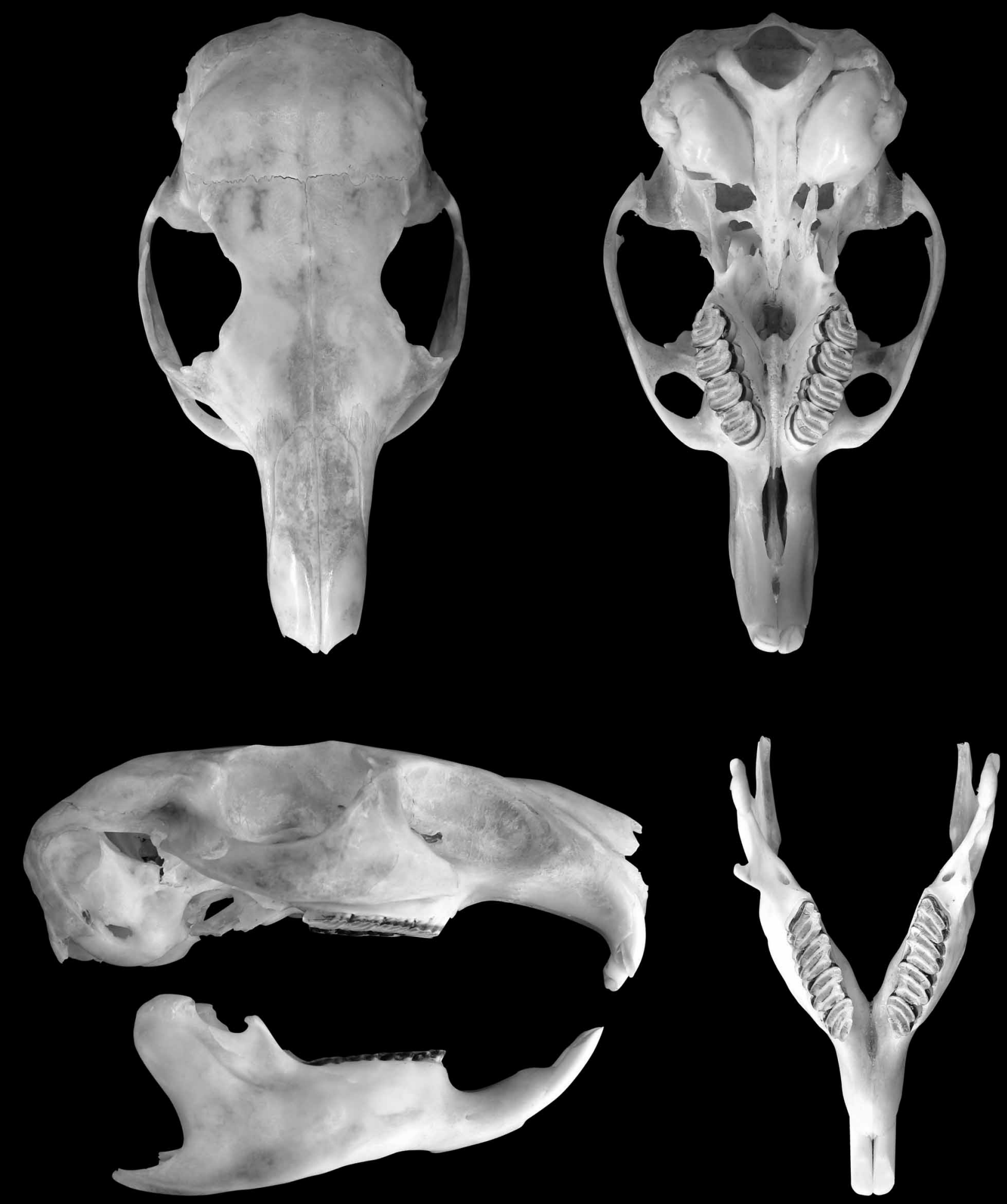

FIGURE 6. Skull of the holotype of Lagidium ahuacaense sp. nov. (MEPN 10237). Scale bar $=10 \mathrm{~mm}$.

Field surveys carried out by KJL and FAW in March and July 2005 and July 2006 suggested that the 120 ha of Cerro El Ahuaca may harbor no more than a few dozen individuals of L. ahuacaense (see also Werner et al. 2006). It remains unknown if additional populations exist elsewhere in southern Ecuador or in adjacent northern Peru. Since these areas are under high human pressure, their exploration is imperative to secure the conservation of possible additional populations. Because the single known population is presumably small 
and extends over a very limited area, Lagidium ahuacaense must currently be considered critically endangered according to IUCN classification (IUCN 2001, IUCN 2008). An effective protection of the population at Cerro El Ahuaca as well as a better understanding of the biology and biogeography of the species is urgently needed to ensure its survival.

\section{Acknowledgments}

We thank A. Arguero and J. L. Román for their assistance with the morphological description of the new species, and H. Zeballos for tissue samples of L. peruanum. Drawings were made by D. N. Karger. We further thank P. Paladines, D. Hidalgo and R. Hidalgo for their cooperation in the field. A. Tejedor provided cranial measurements of L. peruanum specimens deposited at the American Museum of Natural History. V. Pacheco, C. Tello, E. Vivar, R. Cadenillas, and D. Vivas allowed access to the specimen collection of the Museo Historia Natural "Javier Prado" in Lima and provided critical specimen information. Special thanks to J. C. Torres from the Museo Nacional de Historia Natural in Santiago, Chile, to E. Varela and M. Canevari from Museo de Historia Natural "Bernardino Rivadavia" in Buenos Aires and to D. Vertiz and I. Rodriguez from Museo La Plata in Argentina for kindly allowing the first author to revise the collection of Lagidium deposited at their respective institutions. Ministerio del Ambiente in Loja, Ecuador, authorized the collection of material for this study. J. Hentschel, N. Muchhala, C. Roos, T. Wagner and two anonymous reviewers provided valuable comments on earlier versions of the manuscript. Funding was provided by the Zoologische Gesellschaft für Arten- und Populationsschutz (ZGAP, München, Germany). This is publication no. 217 of the Yanayacu Natural History Research Group.

\section{References}

Albuja, L. \& Arcos, R. (2007) Lista de mamíferos actuales del Ecuador. Revista Politécnica 27 (4), Biología, 7, 6-57.

Anderson, S. (1997) Mammals of Bolivia, taxonomy and distribution. Bulletin of the American Museum of Natural History, 231, 1-652.

Anderson, S., Bankier A.T., Barrell, B.G., de Bruijn, M.H.L, Coulson, A.R., Drouin, J., Eperon, I.C., Nierlich, D.P., Roe, B.A., Sanger, F., Schreier, P.H., Smith, A.J.H., Staden, R. \& Young, I.G. (1981) Sequence and organization of the human mitochondrial genome. Nature, 290, 457-465.

Anderson, S., Yates, T. \& Cook, J. (1987) Notes on the Bolivian Mammals 4: The genus Ctenomys (Rodentia, Ctenomyidae) in the eastern lowlands. Novitates, American Museum of Natural History, 2891, 1-20.

Animal Care and Use Committee (1998) Guidelines for the capture, handling, and care of mammals as approved by the American Society of Mammalogists. Journal of Mammalogy, 79, 1416-1431.

Baker, R.J. \& Bradley, R.D. (2006) Speciation in mammals and the genetic species concept. Journal of Mammalogy, 87, 643-662.

Bradley, R.D. \& Baker, R.J. (2001) A test of the genetic species concept: cytochrome- $b$ sequences and mammals. Journal of Mammalogy, 82, 960-973.

Cabrera, A.C. \& Yepes, J. (1960) Mamíferos Sud-Americanos. 2nd ed. Ediar, Buenos Aires, 370 pp.

Canevari, M. \& Vaccaro, O. (2007) Guía de mamíferos del sur de America del Sur. Editorial L.O.L.A. (Literature of Latin America), Buenos Aires, 413 pp.

Eisenberg, J.F. \& Redford, K.H. (1999) Mammals of the Neotropics. The Central Neotropics. Volume 3. Ecuador, Peru, Bolivia, Brazil. University of Chicago Press, Chicago and London, $609 \mathrm{pp}$.

Ellerman, J. (1940) The families and genera of living rodents. British Museum of Natural History, London, 1, 1-689.

Grimwood, J.R. (1969) Notes on the distribution of some Peruvian Mammals. American Committee for International Wild Life Protection and New York Zoological Society, Special Publication, 21, 1-86.

Hasegawa, M., Kishino, H. \& Yano, T. (1985) Dating of human-ape splitting by a molecular clock of mitochondrial DNA. Journal of Molecular Evolution, 22, 160-174.

Higgins, D.G., Bleasby, A.J. \& Fuchs, R. (1992) Clustal V: improved software for multiple sequence alignment. Bioinformatics, 8, 189-191.

Huchon, D. \& Douzery, E. (2001) From the Old World to the New World: a molecular chronicle of the phylogeny and biogeography of hystricognath rodents. Molecular Phylogenetics and Evolution 20, 238-251. 
IUCN (2001) IUCN Red List Categories and Criteria: Version 3.1. IUCN Species Survival Commission. IUCN, Gland, Switzerland and Cambridge, UK. 30 pp.

IUCN (2008) 2008 IUCN Red List of Threatened Species. Available from: http://www.iucnredlist.org (December 2008).

Maddison, W.P. \& Maddison D.R. (1992) MacClade. Version 3.0. Sinauer Associates Inc. Publishers, Sunderland, Massachusetts.

Maniatis, T., Fritsch E.F. \& Sambrock, J. (1992) Molecular Cloning: a Laboratory Manual. Cold Spring Harbor Laboratory Press, Cold Spring Harbor, New York, 754 pp.

Mares, M.A. \& Ojeda, R.A. (1982) Patterns of diversity and adaptation in South American hystricognath rodents. In: Mares, M.A. \& Genoways, H.H. (Eds) Mammalian Biology in South America. Pymatuning Simposia in Ecology 6, Special Publication Series. Pymatuning Laboratory of Ecology, University of Pittsburgh, Pittsburgh, pp. $393-431$.

Mason-Gamer, R.J. \& Kellog, E.A. (1996) Testing for phylogenetic conflict among molecular data sets in the tribe Triticeae (Gramineae). Systematic Biology, 45, 524-545.

Meyen, F.J.F. (1833) Das Vizcacha der Peruaner. Nova Acta Academiae Caesareae Leopoldino-Carolinae Germanicae Naturae Curiosorum, 16, 576-580.

Osgood, W.H. (1943) The mammals of Chile. Zoological Series, Field Museum of Natural History, 30, 1-268.

Pacheco, V. (2002) Mamíferos del Perú. In: Ceballos, G. \& Simonetti, J.A. (Eds) Diversidad y Conservación de los Mamíferos Neotropicales. Instituto de Ecología de la Universidad Nacional Autónoma de México, México, pp. 503-549.

Pearson, O.P. (1948) Life history of mountain vizcacha in Peru. Journal of Mammalogy, 29, 345-374.

Pearson, O.P. (1957) Additions to the mammalian fauna of Peru and notes on some other Peruvian mammals. Breviora, $73,1-7$.

Pearson, O.P. (1995) Annotated key for identifying small mammals living in or near Nahuel Huapi National Park or Lanín National Park, southern Argentina. Mastozoologia Neotropical, 2, 99-148.

Posada, D. \& Crandall, K.A. (1998) Modeltest: testing the model of DNA substitution. Bioinformatics, 14, 817-818.

Puig, S., Videla, F., Cona, M., Monge, S. \& Roig, V. (1998) Diet of the mountain vizcacha (Lagidium viscacia Molina, 1792) and food availability in northern Patagonia, Argentina. Zeitschrift für Säugetierkunde, 63, 228-238.

Redford, K. \& Eisenberg, J.F. (1992) Mammals of the Neotropics: The southern cone. Volume 2. Chile, Argentina, Uruguay, Paraguay. The University of Chicago Press, Chicago, $470 \mathrm{pp}$.

Rowlands, I.W. (1974) Mountain vizcacha. Symposium of the Zoological Society of London, 34, 131-141.

Smithe, F.B. (1975) Naturalist's Color Guide. The American Museum of Natural History, New York. Unpaginated.

Sokal, R.R. \& Rohlf, F.J. (1995) Biometry. The Principles and Practice of Statistics in Biological Research. 3rd Edition. W.H. Freeman \& Company, New York, 887 pp.

Spotorno, A.E., Valladares, J.P., Marin, J.C., Palma, R.E. \& Zuleta, C. (2004a) Molecular divergence and phylogenetic relationships of chinchillids (Rodentia: Chinchillidae). Journal of Mammalogy, 85, 384-388.

Spotorno, A.E., Zuleta, C.A., Valladares, J.P., Deane, A.L. \& Jiménez, J.E. (2004b) Chinchilla laniger. Mammalian Species, 758, 1-9.

Swofford, D.L. (2000) PAUP*, phylogenetic analysis using parsimony (*and other methods). Version 4.01b10. Sinauer Associates, Sunderland, Massachusetts.

Thomas, O. (1907) On a remarkable Mountain Viscacha from Southern Patagonia, with diagnoses of other members of the group. Annual Magazine of Natural History, 19, 439-444.

Thomas, O. (1921) A new Mountain Vizcacha (Lagidium) from N. W. Patagonia. Annual Magazine of Natural History, 7, 179-181.

Voss, R., Lunde, D. \& Simmons, N. (2001) The mammals of Paracou, French Guiana: a neotropical lowland rainforest fauna. Part 2. Nonvolant species. Bulletin of the American Museum of Natural History, 263, 1-236.

Walker, R.S., Ackermann, G., Schachter-Broide, J., Pancotto, V. \& Novaro, A.J. (2000a) Habitat use by mountain vizcacha (Lagidium viscacia Molina, 1782) in the Patagonian steppe. Zeitschrift für Säugetierkunde, 65, 293-300.

Walker, R.S., Pancotto, V., Schachter-Broide, J., Ackermann, G. \& Novaro, A.J. (2000b) Evaluation of a fecal-pellet index of abundance for mountain viscachas (Lagidium viscacha) in Patagonia. Mastozoología Neotropical, 7 , 89-94.

Weir, B. (1974) Some notes on reproduction in the Patagonia mountain viscachas Lagidium boxi (Mammalia: Rodentia). Journal of Zoology, 164, 463-467.

Werner, F.A., Ledesma, K.J. \& Hidalgo, R. (2006) Mountain vizcacha (Lagidium cf. peruanum) in Ecuador - first record of Chinchillidae for the northern Andes. Mastozoología Neotropical, 13, 271-274.

Wilson, D.E. \& Reeder, D.M. (2005) Mammal Species of the World: a Taxonomic and Geographic Reference. Johns Hopkins University Press, Baltimore, 2142 pp.

Woods, C.A., \& Kilpatrick, C.W. (2005) Infraorder Hystricognathi. In: Wilson, D.E. \& Reeder, D.M. (Eds), Mammals Species of the World: a Taxonomic and Geographic Reference. The Johnson Hopkins University Press, Baltimore, pp. 1538-1600. 


\section{Appendix}

\section{Gazetteer and specimens examined}

Specimens of $L$. ahuacaense, $L$. peruanum, $L$. viscacia and $L$. wolffsohni used for morphological and genetic analyses are listed below by collection locality. GenBank accession codes of newly generated sequences are in bold letters. Information for all remaining specimens used in the phylogenetic analysis is given in Spotorno et al. (2004a). Administrative districts (provinces, departments) are underlined. Information on geographic coordinates and altitude of the examined specimens, when available, are provided in parentheses. For $L$. peruanum, L. viscacia and $L$. wolffsohni specimens, geographical information was obtained from museum databases and referential information on location. Genders are given in parentheses, when known. Acronyms for institutions are: MEPN, Museo de la Escuela Politécnica Nacional, Quito, Ecuador; LCM, Laboratorio de Citogenética de Mamíferos, Santiago, Chile; MUSM, Museo de Historia Natural "Javier Prado", Universidad Nacional Mayor de San Marcos, Lima, Peru; AMNH, American Museum Natural History, New York, United States; MNHN, Museo Nacional de Historia Natural, Santiago, Chile; MLP, Museo de La Plata, La Plata Buenos Aires, Argentina; MACN-Ma, Mastozoology Department, Museo Argentino de Ciencias Naturales "Bernardino Rivadavia", Buenos Aires, Argentina.

Lagidium ahuacaense sp. nov.

ECUADOR

Loja

Cerro El Ahuaca, Cariamanga $\left(04^{\circ} 18^{\prime} 29^{\prime \prime} \mathrm{S}, 79^{\circ} 32^{\prime} 47^{\prime \prime} \mathrm{W}, 2450 \mathrm{~m}\right)$. Holotype MEPN 10237 (male), and a second specimen released after the taking of a blood sample for genetic analysis. GenBank access number for the sequence is EF638793.

\section{Lagidium peruanum}

PERU

Arequipa

Toccra. LCM 2665 (EU275765).

Arequipa city surroundings. LCM 2575 (EU275766), LCM 2576 (EU275767).

Cajamarca

Asunción, Cerro El Poyo. MUSM 23175.

$\underline{\text { Junin }}$

Junin. MUSM 5995.

Carhuamayo, Capilla Cocha (1055'S, $\left.76^{\circ} 03^{\prime} \mathrm{W}, 4500 \mathrm{~m}\right)$. MUSM 2197, MUSM 2202, MUSM 2171, MUSM 2182 (2 females, 2 males).

Laguna Junin o Chinchaicocha $\left(76^{\circ} 07^{\prime} \mathrm{W}, 11^{\circ} 01^{\prime} \mathrm{S}\right)$ (4000 m). MUSM 2205 (1 male).

Cau-Cau $\left(11^{\circ} 15^{\prime} \mathrm{S}, 75^{\circ} 59^{\prime} \mathrm{W}\right)$. MUSM 2172, MUSM 2185, MUSM 2184, MUSM 2230 ( 2 females, 2 males).

$\underline{\text { Lima }}$

Huarochiri $\left(11^{\circ} 37^{\prime} \mathrm{S}, 76^{\circ} 26^{\prime} \mathrm{W}, 3960 \mathrm{~m}\right)$. MUSM 618 (male).

Huarochiri $\left(12^{\circ} 06^{\prime} \mathrm{S}, 76^{\circ} 12^{\prime} \mathrm{W}, 3800 \mathrm{~m}\right)$. MUSM 2200 (female).

Pariachaca $\left(11^{\circ} 36^{\prime} \mathrm{S}, 7^{\circ} 24^{\prime} \mathrm{W}, 4200 \mathrm{~m}\right)$. MUSM 2199 (male).

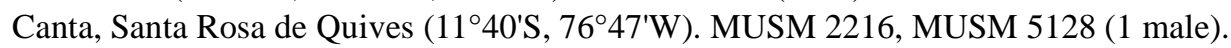

Moquegua

Mariscal Nieto, Torata (3420m). MUSM 13112.

Pasco

$\mathrm{Km} 20$ of the road between Carhuamayo and Paucartambo $\left(10^{\circ} 42^{\prime} \mathrm{S}, 75^{\circ} 80^{\prime} \mathrm{W}\right)$. MUSM 2206 (1 male).

Chipa $\left(10^{\circ} 36^{\prime} \mathrm{S}, 7^{\circ} 54^{\prime} \mathrm{W}\right)$. AMNH 60571, AMNH 60572, AMNH 60574, AMNH 60575, AMNH 60576, AMNH 60595, AMNH 60596 (1 female, 6 males).

$\underline{\text { Puno }}$

Cotacollo, Plateria (15 $\left.{ }^{\circ} 55^{\prime} \mathrm{S}, 6^{\circ} 49^{\prime} \mathrm{W}\right)$. MUSM 2209, MUSM 2198, MUSM 2214 (1 female, 2 males).

Atuncolla $\left(15^{\circ} 43^{\prime} \mathrm{S}, 70^{\circ} 09^{\prime} \mathrm{W}\right)$. MUSM 2186, MUSM 2195 (1 female, 1 male).

Huacullani. LCM 3100 (EU275762).

Puno city surroundings (1554'S, 7000’W, 4092m). LCM 2912 (EU275763), LCM 2913 (EU275764).

Lago Titicaca, Moho ( $\left.15^{\circ} 21^{\prime} \mathrm{S}, 6^{\circ} 30^{\prime} \mathrm{W}, 3920 \mathrm{~m}\right)$. MUSM 2225 (1 female).

Tacna

Candarave $\left(16^{\circ} 53^{\prime} \mathrm{S}, 70^{\circ} 19^{\prime} \mathrm{W}\right)$. MUSM 2201 (1 female).

Lagidium viscacia

CHILE

$\underline{\text { Santiago }}$ 
Quebrada Macul. MNHN 663.

ARGENTINA

Chubut

Chubut MLP 377, MLP 520.

Cushamen. MACN-Ma 16473, MACN-Ma 16521 (1 male).

Jujuy

Rio Coyaguaima (4000 m). MACN-Ma 39.499, MACN-Ma 39.500 (1 male).

La Rioja

La Rioja. MACN-Ma 16330 (1 male).

Aimogosta. MACN-Ma 14.16.

Velazco, Puerto Viejo (2500 m). MACN-Ma 34.210, MACN-Ma 34.218 (1 female, 1 male).

Velazco, East of Melchor (2500 m). MACN-Ma 34.219, MACN-Ma 34.233 (2 females).

Velazco, San Jeronimo (2900 m). MACN-Ma 34.230, MACN-Ma 34.254, MACN-Ma 34.255, MACN-Ma 34.256,

MACN-Ma 34.263 (2 females, 2 males).

Neuquen

Catan-Lil Las Coloradas, Estancia Campo Grande (1000 m). MACN-Ma 13620, MACN-Ma 14312 (1 female, 1 male).

San Carlos de Bariloche. MLP 22 IV.47.2, MLP 22 IV.47.3, MLP 22.IV.47.4.

Rio Negro

Norquinco. MACN-Ma 13932, MACN-Ma 13933, MACN-Ma 16474 (3 males).

Bariloche, El Bolson. MACN-Ma 13936 (1 male).

Valcheta, Campana Mahuida. MACN-Ma 14308, MACN-Ma 14309, MACN-Ma 14310 (2 females, 1 male).

Pilcaniyeu, Pilcaniyeu, MACN-Ma 14313, MACN-Ma 44.25 (1 male).

$\underline{\text { Salta }}$

Chorrillos (4700 m). MACN-Ma 30.114 (1 male).

$\underline{\text { San Juan }}$

San Guillermo. MACN-Ma 18829 (1 female).

Tucuman

Sierras. MACN-Ma 4.381.

Lagidium wolfssohni

CHILE

Region del Aysen

Estancia Chacabuco, Cochrane. MNHN s.n. 